\title{
Stock return volatility and capital structure measures of nonfinancial firms in a dynamic panel model: Evidence from Pakistan
}

\author{
Zeeshan Ahmed (D) | Daw Tin Hla
}

Department of Accounting and Finance, Faculty of Economics and Business, Universiti Malaysia Sarawak (UNIMAS), Kota Samarahan, Malaysia

\section{Correspondence}

Zeeshan Ahmed, Department of Accounting and Finance, Faculty of Economics and Business, Universiti Malaysia Sarawak (UNIMAS), Kota Samarahan, Malaysia.

Email: zeeshan4282@gmail.com

\begin{abstract}
We investigate the impact of stock return volatility on different capital structure measures of nonfinancial firms in a dynamic panel model. Two-step system generalized method of moment dynamic panel estimator is applied to nonfinancial sector's data from Pakistan Stock Exchange over the period 2001-2014. The results imply that stock return volatility has a significant negative impact on book leverage and long-term market leverage ratios. However, stock return volatility causes the increase in total market leverage ratios. Moreover, book leverage and long-term market leverage of firms decrease as a result of an increase in stock return volatility in different classification of firms. Conversely, stock return volatility has a significant positive impact on total market leverage ratios in those classifications of firms. Capital structure decisions are more sensitive to stock return volatility as default risk increases. Firms significantly go for the reduction in their debt financing due to high stock returns volatility and to avoid from possible consequences of default. The results are robust to alternative measures such as cash flow volatility and earnings volatility.
\end{abstract}

\section{KEYWORDS}

capital structure measures, dynamic panel model, nonfinancial firms, stock return volatility, system GMM

\section{1 | INTRODUCTION}

Capital structure determinants have been an issue of considerable debate, among which stock return volatility greatly influences the capital structure. It is one of the puzzling and striking features of corporate finance that happens due to the fluctuations in the price of stocks and consequently changes the financial decisions (Welch, 2004). Not surprisingly, this stock return volatility witnesses a dramatic and shocking effect on corporate capital structure in both developed and developing countries. Moreover, the stock returns of firms operating in developing countries are highly volatile, and firms are incapable to fulfil the debt obligations (Andrade \& Kaplan, 1998). These firms are unsure about their future earnings and investments that can be used to pay debt obligations. Moreover, firms owing high stock return volatility face high cost of external capital, and decreasing ability in the payment of loans might cause high financial distress cost. In such a situation, firm prefers the reduction in debt financing to avoid from possible consequences of default (Dudley \& James, 2015). If there is little or no debt in capital structure, then firm will not be in danger of default and no potential bankruptcy cost 